\title{
There is no one way to internationalization at home: Virtual mobility and student engagement through formal and informal approaches to curricula
}

\author{
Belem Barbosa, Claudia Santos \\ \& Cláudia M. Prado-Meza
}

Abstract:

Internationalization at Home (laH) is the most accessible approach for internationalizing education, as it does not involve mobility or considerable investment. This article discusses results of two distinct laH initiatives: a 4-week collaboration between students from a Portuguese university and a Mexican university, and a set of activities conducted throughout one semester in a multicultural classroom in one Portuguese university. The analysis shows that, despite the clear differences of the two initiatives, they provided very interesting outcomes, with students recognizing the development of intercultural communication skills and other soft skills, which were perceived as adding value to the learning process and to their future professional careers.

Keywords:

internationalization of higher education; internationalization of the curricula; classroom collaboration; multicultural classroom. 


\section{Não há uma forma única para a internacionalização em casa: mobilidade virtual e envolvimento dos estudantes em abordagens formais e informais dos curricula}

Resumo: Internacionalização em casa (laH) é a abordagem mais acessível para a internacionalização do ensino, já que não envolve mobilidade ou investimento consideráveis. Este artigo discute os resultados de duas iniciativas distintas de laH: uma colaboração de quatro semanas entre estudantes de uma universidade portuguesa e uma universidade mexicana, e um conjunto de atividades realizadas ao longo de um semestre numa turma multicultural de uma universidade portuguesa. A análise mostra que, apesar das claras diferenças das duas iniciativas, elas produziram resultados muito interessantes, com os alunos a reconhecerem o desenvolvimento de competências de comunicação intercultural e outras soft skills, que foram percebidas como agregando valor ao processo de aprendizagem e às suas futuras carreiras profissionais.

Palavras-chave: internacionalização do ensino superior; internacionalização dos planos de estudos; colaboração entre turmas; turmas multiculturais.

\section{No hay una forma única de internacionalización en casa: movilidad virtual y envolvimiento de los estudiantes a través de enfoques formales e informales de los curricula}

Resumen: La internacionalización en casa $(\mathrm{laH})$ es el enfoque más accesible para la internacionalización de la educación, al no implicar movilidad una participación considerable. Este artículo analiza los resultados de dos iniciativas distintas de laH: una colaboración intercontinental de 4 semanas entre estudiantes de una universidad portuguesa y una universidad mexicana, mientras que la segunda es sobre un conjunto de actividades realizadas durante un semestre en un aula multicultural en una universidad portuguesa. El análisis muestra que, a pesar de las claras diferencias de las dos iniciativas, se observaron resultados muy interesantes, los estudiantes reconocieron el desarrollo de habilidades para la comunicación intercultural entre otras habilidades interpersonales, las cuales se perciben como un valor agregado para el proceso de aprendizaje y para sus futuras carreras profesionales.

Palabras clave: internacionalización de la educación superior; internacionalización de los planes de estudio; colaboración en el aula; aula multicultural.

\section{II n'a pas une solution unique pour l'internationalisation à la maison: mobilité virtuelle et implication des étudiants dans des approches curriculaires formelles et informelles}

Résumé: L'internationalisation à la maison (laH) est l'approche la plus accessible pour acquérir l'internationalisation de l'enseignement, car elle n'implique pas de mobilité ou d'investissement considérable. Cet article discute les résultats de deux initiatives distinctees à l'laH: une collaboration intercontinentale de quatre semaines entre des étudiants d'une université portugaise et d'une université mexicaine, et un ensemble d'activités menées pendant un semestre d'une classe multiculturelle dans une université portugaise. Malgré les différences évidentes entre les deux initiatives, les deux cas ont présenté des résultats très intéressants, parmi lesquels les élèves ont développé des compétences en communication interculturelle et d'autres compétences non techniques, qui étaient perçues comme une valeur ajoutée au processus d'apprentissage, ainsi qu'une adjonction à leur future carrière professionnelle.

Mots-clés: internationalisation de l'enseignement supérieur; internationalisation des programmes d'études; collaboration en classe; classes multiculturelles. 


\section{Introduction}

In higher education institutions (HEl), the concept of internationalization can be defined as "the process of integrating an international dimension into the teaching, research, and service functions of an institution of higher education" (Knight, 2015, p. 2). Knight (2004) explains that this can be achieved by a variety of strategies, including encouraging students to study abroad, recruiting foreign students, strengthening cooperation with universities overseas, integrating international knowledge emerging from other cultural contexts into the curriculum, and promoting the publication of articles in international journals. Knight (2015) argues that internationalization of HEl comprises two essential pillars: at-home and cross-border. One of the most notorious facets of cross-border internationalization is student mobility, which receives great attention from the extant literature. The other probably under-estimated and less-discussed aspect of internationalization is the so-called Internationalization at Home (laH), which is the focus of this article.

While the concept of internationalization has been extensively discussed, recent trends seem to concentrate on how internationalization can be identified and improved (Gao, Baik, \& Arkoudis, 2015). This article follows this trend, aiming at contributing to the dissemination and improvement of laH. Despite its relevance amongst the most innovative teaching strategies, laH is still disregarded by many teachers and almost unknown by students. Considering that the debate and sharing of experiences is essential to both foster its adoption and find ways to more effectively design future initiatives, this article presents and discusses two different laH projects implemented at a Portuguese university - one that could be designated as virtual mobility, and another built on the international and cultural diversity of a classroom.

\section{Literature review}

According to Beelen and Jones (2015, p. 69), laH is "the purposeful integration of international and intercultural dimensions into the formal and informal curriculum for all students within domestic learning environments". Compared to cross-border (i.e., the mobility of students and staff), this is a more versatile teaching-learning modality that can include all students, namely the ones that are not able to participate in mobility programs. The acknowledgment that students who remain in their home country will also need to interact with culturally diverse customers and peers in their future professional lives (Harrison, 2015) favors the expected growing tendency of $\mathrm{laH}$, although these initiatives should be seen as a means to an end (quality improvement) and not as a goal in itself (de Wit, 2015; de Wit \& Leask, 2015). laH can be implemented in almost every dimension of the teaching/learning process (e.g., syllabus, learning outcomes, methodology, assessment), one characteristic that, together with imagination and time from education practitioners, may achieve quite interesting results. 
laH comprises several modalities, one of them being virtual mobility, classified by Jones (2016) as initiatives that use technology to share cultural experiences. One should note that virtual mobility is the term usually adopted in Europe, whereas in America De Wit (2013) notes that the use of Collaborative Online International Learning (COIL) is more common. It is possible, therefore, to have classrooms in different countries exchanging information or collaborating in joint projects. As explained in detail by Rubin (2016), virtual mobility stands out as an education model and as a new approach to teaching and learning by classrooms in different countries, comprising interaction, experiential learning, and the development of joint tasks. Amongst the expected benefits of this type of laH initiatives is the development of intercultural skills (Rubin, 2016). Despite the growing popularity of virtual mobility, with several universities in Europe and North America developing their own COIL offices (e.g., SUNY COIL Center at the State University of New York), extant literature offering evidence on students' views and on the learning impacts of virtual mobility is still insufficient. Some important contributions include the studies by Soria and Troisi (2014) and Rossini, Rincón, and Rutkowski (2015), which confirm the efficacy of virtual mobility to develop intercultural communication skills and the positive impact on student satisfaction.

Another clear trend in HEl is the campus cultural diversity (Jones, 2016; Leask, 2009). Consequently, an important modality of laH refers to taking advantage of multicultural classrooms in case there is a high number of international students. As Harrison (2015) mentions, encounters between home and international students in the classroom are becoming increasingly frequent, particularly in the humanities and social sciences, finding more resistance from technology and sciences scholars. Horn, Hendel, and Fry (2012) and Jones (2013) stress the potential of multicultural classrooms to purposefully develop intercultural competencies in both domestic and international students. Indeed, Arkoudis et al. (2013) believe that academics should take advantage of these opportunities that are many times underused, as peer interaction can provide a greater sense of belonging with positive impacts on students' learning achievements. This can be reached by implementing an inclusive approach and valuing cultural insights, that is, using the classroom's cultural capital.

Although interactions between home and international students can be held both in and beyond classrooms (Horn, Hendel, \& Fry, 2012; Jones, 2013), some students have difficulties initiating interaction with foreign students (Harrison, 2015), namely due to language barriers, anxiety, and fear of being judged or inadequate. Hence, although students are expected to seek and be motivated to engage in intercultural experiences, their initial proneness tends to be low (Harrison, 2015). Moreover, on campus, opportunities for engagement between home and international students are not a commonplace, as these two groups "often inhabit quite separate worlds" (Baldassar \& McKenzie, 2016, p. 94). Arguably, teacher initiatives to foster interaction between home and international students in classrooms are essential for taking advantage of multicultural campuses. 
As wisely observed by Robson (2017), if universities want to become really international, they should start at home. The relevance of laH strategies is directly linked to the real impact they may have on students. One of the most cited studies that aimed to measure the impact of laH on students' competencies was conducted by Soria and Troisi (2014) in the United States. These authors found that participating in laH activities can promote intercultural competencies as effectively as formal study abroad. Considering the interaction with international students on campus, Baldassar and McKenzie (2016) state that laH is also expected to offer similar benefits to studying abroad. Beelen and Jones (2015) argue further, stating that intercultural learning depends on the effective articulation and assessment of learning outcomes in specific disciplines, hence depending on classroom management and group tasks. Similarly, Leask (2009) supports the idea that positive outcomes from interaction between home and international students are highly dependent on the way academics use both formal and informal curricula, since the fact that domestic and international students may share the same physical space does not necessarily result in a meaningful interaction.

Thus, extant literature points to the assumption that laH contributes to the preparation of students for a global and interconnected world and for better addressing global problems (Agnew \& Kahn, 2014). The efficacy of such strategies will depend on the redefinition of classrooms and campuses to enable experiences and develop the ability to deal with international and intercultural environments.

Still, the implementation of laH practices is not an easy task. Further to difficulties inherent to the application of laH strategies, additional challenges are expected from students themselves, who often show resistance and lack of motivation to work with their international peers, fearing to damage their academic success in terms of grades, and to be misunderstood and embarrassed (Harrison, 2015). In fact, Harrison (2015) points anxiety as an important obstacle that can prevent students from developing intercultural competencies when dealing with laH. Therefore, coping with the anxiety of undergraduate students is particularly important to guarantee that they acquire the intended skills.

Challenges are inherent to all new approaches, and, as previously discussed, it is widely accepted that intercultural competencies are essential for the future professional and personal development of graduate and post-graduate students. Generally, there seems to be ample agreement on the fact that laH initiatives can indeed offer versatile opportunities for their development. As Leask (2009) poses it, intercultural competencies are key outcomes of an internationalized curriculum.

\section{Method}

This article adopts a case-study approach following Yin (2017), by presenting and discussing data collected in two laH initiatives designed by the authors. The learning outcomes of the initiatives comprised (i) the development of intercultural skills and (ii) the development of 
communication and collaboration skills within international teams. A qualitative approach was adopted, using participant observation and focus groups as techniques for collecting data.

The first initiative with laH practices took place in a multicultural classroom in one Portuguese University in 2016, where a set of activities were conducted throughout one semester in the subject Business English 1 of the Bachelor's degree in Marketing. The learning process contemplated a series of assignments geared towards the integration of international students' experiences in the class and the development of intercultural competencies through formal and informal interaction, as advocated by Arkoudis et al. (2013). The class was composed of 25 Portuguese students and 12 international students. Data were collected by participant observation, following the procedures recommended by Bryman (2012). The teacher acted as a participating observer, as she was fully involved in the group activities but assuming her role of teacher, and consequently not as a full member. Data collection relied on observation and field notes, particularly during the group evaluation of each task, where students were invited to share their opinions on what they had learned and the skills they were developing. Other sources of information included the materials students produced (e.g., presentations) and informal comments on the activities. Considering the short duration (15 weeks), the limited setting (the classroom), and the focus on a very particular topic (i.e., the development of soft skills, e.g., intercultural, communication, teamwork), the research is according to what Wolcott (1990) designates micro-ethnography.

The second initiative consisted in an international online collaboration between two classrooms, one in Portugal and another in Mexico. As explained in the previous section, this is often designated as virtual mobility. A total of 33 students were involved, 23 enrolled in a Digital Marketing course of a Bachelor's degree in Marketing in Portugal, and 10 enrolled in the Integrative Business Management Workshop of a BA in International Business in Mexico. They were all $5^{\text {th }}$-semester students. The collaboration activity was operationalized with the support of the Columbus Hub Academy ${ }^{1}$ in the fall semester of 2016 and lasted four weeks. In order to collect students' perceptions and assessment of the activity, the authors conducted three focus groups with a total of 22 students. This is a technique that has been used by extant literature to evaluate the impact of laH initiatives (e.g., Leask, 2009). Ethical principles commonly accepted for social research (Bryman, 2012) were applied, namely by obtaining informed consent and making the research anonymous, voluntary, and confidential. The focus group outline comprised two questions about: (i) the advantages and difficulties of the activity, and (ii) skills developed during the activity. Thematic analysis was undertaken by two researchers, by coding themes and subthemes that emerged from the data.

\section{Results}

\section{laH first experience}

This experience was implemented in the fall semester of 2016 in Business English 1, a subject of the Bachelor's degree in Marketing. The high number of international 
students generated the opportunity to apply laH activities within the classroom, where formal and informal content concurred to the development of intercultural awareness. Some initial orientations for the class included calling every student by name and always scattering international students across the groups, thus centering the approach on in-class proximity and familiarity, closely following Arkoudis et al. (2013) recommendations on building confidence beyond students' cultural and social groups. As it was a foreign language subject, students were requested to always communicate in English.

The syllabus was prepared so as to encompass international and intercultural content material and students were encouraged to work on unknown topics and discuss them, contributing to the class as a whole with different perspectives and examples. To further exemplify assignments dedicated to multicultural topics, the following material was included: i) a text on internationalization of companies provided opportunity for students to consider globalization in a business context and to be aware of other ways of acting and thinking; ii) an oral presentation on cultural differences motivated students to be acquainted with the importance these factors can have on the success of a business and how it can impact on the conduct and productivity of companies. In this specific activity, international students were asked to prepare a presentation on Portuguese people, facing home students with interesting stereotypes and stimulating debate.

The examples listed above and similar assignments contributed to the development of several competencies, including teamwork, critical thinking, content analysis, communication, and, of course, linguistic proficiency in English. Furthermore, by joining home and international students in collaborative work, it was possible to reflect in a more holistic way on a diverse set of issues: the complexity and interdependence of business settings, the role of judgment and misconceptions on personal relationships, the notion of space and distance, the 'self' and its place in the global society, distinguished ways of verbalizing, the use of body language, the consciousness of time, among others. In addition, contextualized contributions from students of different nationalities with distinct experiences and mindsets were a priceless source for insights on the class topics. A special moment was reserved for international students to present their home country and university via PowerPoint presentations and other materials they would care to bring to class, such as videos, songs, treats, and photographs.

From all the activities held in class during that semester, two were particularly cherished: the intercultural coffee break and the international dance show. These were activities in the informal (co)curriculum that were chosen/suggested by the students themselves as a way to further share their national culture with their classmates. As suggested by Leask (2009), combining formal and informal curricula fosters intercultural engagement and meaningful interactions. Students were invited to bring traditional food dishes to the last class and share them with colleagues. As international students normally cannot buy their home-country delicacies in the host country, many had to bake them, evidencing their 
commitment to the occasion. The international dance show was a unique and engaging experience and a true intercultural moment. Portuguese students presented folk dances of all countries that were represented by international students enrolled in Business English 1. The show was secretly prepared and it was a moving moment for international students, where everybody was invited to dance and sing spontaneously. This inclusive and informal approach was quite successful in making use of cultural diversity. In order to avoid stereotypes, these activities were afterwards discussed in class, so students could explore the origins of each tradition, and the commonalities and particularities of different cultures, hence maximizing the intercultural learning. As explained by Jones (2016), these alternative perspectives of other cultures are expected to question beliefs and mindsets and thus have a relevant impact on intercultural skills. This was empirically supported by this initiative, as students acknowledged learning about other cultures and being more confident and able to interact with people from diverse cultural settings.

Regarding learning outcomes, this set of activities produced promising results in terms of soft skills, where class dynamics was many times generated by students themselves as a response to diverse levels of interaction, providing support to indications by extant literature (e.g., Jones, 2016; Leask, 2016). Overall, students demonstrated they understood the purpose of the activities as recommended by Leask (2009), and acknowledged the development of important soft skills such as teamwork, critical-thinking, problem-solving and organization tasks. These findings are in line with the ones obtained by Leask (2009). Furthermore, the international and intercultural content material allowed for the implementation of multi-layered teaching methodologies, where home and international students constructed their own knowledge, maximizing the immersion experience of all participants, both teacher and students.

According to the feedback provided by the exchange students that participated in these activities, their mobility experience was reinforced, not only due to the strengthening of relationships with home students but also to the association of the classroom to positive feelings of inclusiveness. In addition, home students benefited from the presence of international students in the classroom at several levels: i) at a linguistic level, since it was mandatory to speak English at all times, including the need to understand different accents and phraseology, thus improving their hard skills on the subject; ii) at a cultural level, as the myriad of nationalities and the exchange of experiences was strongly felt; iii) at employability level, since content material allowed for the discussion of business topics and evidenced the plasticity professionals should have today when faced with international job opportunities; iv) at competencies level in general, Portuguese students had a real chance of experiencing laH and developing a broad range of skills. The success of these and similar activities demonstrates that the classroom is a privileged space for personal growth and interaction between nations, as underlined by Leask (2009), and that the interdependence of the formal and the informal curricula is a crucial factor for intercultural engagement. 


\section{laH second experience}

The second initiative involved one university from Portugal and another from Mexico, and consisted of a collaborative project featuring the conception of an internationalization plan for a Mexican association of salt producers. Portuguese students acted as digital marketing consultants, assisting Mexican students with the development of a website and maintaining regular online conference calls, email and online chats, presenting videos that were shared online, and recording class presentations. Mexican students had the chance to vote for the best website, taking part in the assessment of Portuguese students. In addition, the results were presented to the Mexican association of salt producers, who discussed the outputs of the activity. The project contemplated formal and informal moments, generating a dynamic interplay among students. English was the only language used for this project, considering participants' adequate level of proficiency.

Primary data for the analysis of the project was collected through focus groups conducted in Portugal and in Mexico, where students shared their views on the advantages and challenges of participating in the initiative, the impact on their learning process, and the skills they developed. Across focus groups, students agreed that this was an interesting and valuable experience for them. Students recognized their confidence grew with the interaction with their peers:

I think everybody was really nervous, because we didn't know what to expect from the [Portuguese] students, and I think they were feeling the same, nervous because of us, but at the end we actually knew what we were doing and the nervousness just went away. (...) I think we established a connection, even though we were in a totally different country. (Focus group 3, Mexico)

Interestingly, students were both curious about their partners' competencies and committed to impressing them with theirs, which often surpassed their desire to impress the teachers. A clear advantage was the added motivation associated with this initiative. One of the participants explained that one main reason is the novelty of the activity, generating a high level of satisfaction and enthusiasm:

I think that just the fact of having a different approach motivates us. (...) We have done lots of assignments, and the fact that we have now this type of assignment, a different one, it motivates us because it is something we haven't done so far. (Focus group 1, Portugal)

There were also testimonials on difficulties, the main ones being time differences, language, and being unable to meet in person. Still, students described interpersonal communication difficulties as similar to professional life situations and as an opportunity 
to develop their soft skills. The impact the initiative had on students was considered relevant. Students reported it made them change the way they collaborate in academic assignments. In this regard, three aspects stood out: they worked more closely together, met more often, and had to decide under pressure:

We were working as if in a company, everyone had to work towards the same goals and make decisions together [during the video conferences], and because of that we had to meet more often. (Focus group 1, Portugal)

Several soft skills were spontaneously mentioned in the discussions, some more specific to peer interaction, such as teamwork, tolerance, negotiation, giving in, compromising, and others more general, such as managing time, adapting to constraints and dealing with pressure. Also mentioned were language skills and being able to deal with people from different cultures. Indeed, students' narratives evidenced that they were able to develop a wide range of skills with this experience:

It demonstrates the ability of teamwork more than everything, and (...) you have to adapt to what the other people are thinking and in everyday life you are going to work with different people and you have to be "adaptable". (Focus group 3, México)

Moreover, and similarly to the results obtained by Rossini, Rincón and Rutkowski (2015), the participants clearly related the developed skills to both their personal and their future professional lives. They were optimistic that experiences such as this one would be valued by future employers. They highlighted their enhanced competencies, which they expect to be useful in their professional careers, and impact their future success:

It prepares us, because in the future, in a company, if we have to deal with complete strangers, the experience could scare us, but now we know how to deal with it. (Focus group 2, Portugal)

For the Portuguese students, the assignment was a close adaptation of another one that had been part of the course's evaluation in previous years, thus allowing some comparison of the outputs produced. With the collaboration, students were more motivated, worked harder, the outputs produced (i.e., video presentations and website proposals) were more carefully developed, and the standard deviations of the grades were much lower. Thus, this international collaboration project had a positive effect on the learning process of the students involved, both by developing additional skills (e.g., intercultural and communication skills) and by fostering students' motivation and 
effort, leading us to conclude that the benefits of the collaboration may have exceeded the ones foreseen. Those multidimensional indicators, as Leask (2009, p. 210) states, "clearly link internationalisation to globalisation, to intercultural learning, to an awareness of the cultural foundations and constructions of knowledge and action, and to cultural awareness in relation to self and others".

\section{Conclusion}

This paper demonstrates the positive the impacts of laH on students, namely regarding motivation, satisfaction, and the development of professional competencies, as well as expectations about the value of such experiences for their future employability. Overall, the results are in line with extant literature (e.g., Rossini, Rincón, \& Rutkowski, 2015; Soria \& Troisi, 2014) providing positive signs on laH ability to develop relevant soft skills. Attitudes of resistance and mistrust, as the ones referred by Harrison (2015), were not felt in both experiences, demonstrating that students value the opportunity to interact with other cultures and participate in innovative teaching/ learning experiences. In fact, novelty has been an important stimulus for students, who reported their enthusiasm and promptitude in trying out new teaching methods. The teachers who implemented the activities also recognize that, generally, this stronger stimulus resulted in higher levels of engagement and participation inside and outside the classroom, and better grades when compared to other colleagues in similar tasks but with no international peers involved.

As referred by Guri-Rosenblit (2015), the widening of access to higher education, the generalization of digital technologies and the knowledge economy, among other factors, demand new learning approaches. Agnew and Kahn (2014), underline that in order to be global educators and agents of change, scholars have to acquire new skills themselves and new perspectives of the world and their work, stating that teachers are also expected to acquire new identities and go through experience transformations to be able to enhance multicultural competencies in students.

Limitations of our study include the fact that data refers solely to two activities, comprising a limited number of students. Thus, despite the interesting and enticing cues, results should be interpreted with caution, since they are not representative and therefore should not be generalized prior to a replication of the study. It is also important to note that the researchers analysed the effect of practices that were designed and executed by them. Data collection and analysis procedures were conducted in order to minimize the risk of bias, still one may consider some risk of being more prone to perceiving positive effects.

With this article, we expect to encourage the widespread use of laH among faculty, thus maximizing the impact similar initiatives could have by actively including international relevant content in the formal and informal curricula. Obviously, in line with the 
recommendations offered by extant literature (e.g., de Wit \& Leask, 2015; Jones, 2016; Leask, 2009) and as illustrated by this article, ideally these initiatives should not be isolated; on the contrary, they should be transversal to a study programme, by incorporating an intercultural dimension that could permeate its entire curriculum and highlight the development of intercultural skills in the general learning outcomes. Considering this is an inclusive and democratic internationalization methodology available to all students and institutions, laH dissemination depends essentially on the individual willingness of education practitioners and on institutional support. In fact, and taken from a different perspective, the absence of these initiatives would mean a waste of potential resources, namely in $\mathrm{HEI}$ which receive a considerable number of internationally mobile students.

Apparently, the number of articles in top-ranked journals about laH has grown significantly in 2015 and 2016, but without the expected continuity. More studies are needed to facilitate the adoption and democratization of those practices, describing and evaluating different ways of applying laH, but also measuring the impacts, something that can be done through the assessment and acquisition of multicultural competencies and other soft skills associated to these activities, or identifying impacts for example in terms of employability and professional success of students previously involved in this type of teaching/learning strategies. Moreover, it is recommended the use of adequate research techniques to collect relevant data. This article uses two qualitative techniques (participant observation and focus groups) that were valuable tools to assess the impact of the $\mathrm{laH}$ activities. Future research can also use interviews and quantitative approaches to further contribute to the understanding of the impacts of laH.

\section{Notes}

1 The Columbus Hub Academy (https://www.columbus-hubacademy.org/) is a platform that enables the design and implementation of online international teaching and learning projects among the members of Columbus and the European University Association.

\section{References}

Agnew, M., \& Kahn, H. E. (2014). Internationalization-at-home: Grounded practices to promote intercultural, international, and global learning. Metropolitan Universities, 25(3), 31-46.

Arkoudis, S., Watty, K., Baik, C., Yu, X., Borland, H., Chang, S., . . Pearce, A. (2013). Finding common ground: enhancing interaction between domestic and international students in higher education. Teaching in Higher Education, 18(3), 222-235.

Baldassar, L., \& McKenzie, L. (2016). Beyond "just being there” Teaching internationalization at home in two qualitative methods units. Teaching Sociology, 44(2), 84-95.

Beelen, J., \& Jones, E. (2015). Redefining internationalization at home. In A. Curai, L. Matei, R. Pricopie, J. Salmi, \& P. Scott (Eds.), The European higher education area: Between critical reflections and future policies (pp. 59-72). Dordrecht: Springer. 
Bryman, A. (2012). Social Research Methods (4th ed.). Oxford: Oxford University Press.

de Wit, H. (2013). COIL - Virtual mobility without commercialisation. University World News. Retrieved from https://www.universityworldnews.com/post.php?story=20130528175741647

de Wit, H. (2015). Internationalization misconceptions. International Higher Education 64, 6-7.

de Wit, H., \& Leask, B. (2015). Internationalization, the curriculum and the disciplines. International Higher Education, 83, 10-12.

Gao, Y., Baik, C., \& Arkoudis, S. (2015). Internationalization of higher education. In J. Huisman, H. de Boer, D. D. Dill \& M. Souto-Otero (Eds.), The Palgrave International Handbook of Higher Education Policy and Governance (pp. 300-320). London: Springer.

Guri-Rosenblit, S. (2015). Internationalization of Higher Education: Navigating between contrasting trends. In A. Curaj, L. Matei, R. Pricopie, J. Salmi \& P. Scott (Eds.), The European Higher Education Area (pp. 13-26). Cham: Springer.

Harrison, N. (2015). Practice, problems and power in 'internationalisation at home': Critical reflections on recent research evidence. Teaching in Higher Education, 20(4), 412-430.

Horn, A. S., Hendel, D. D., \& Fry, G. W. (2012). The empirical basis for adopting a civic rationale for internationalization. Higher Education, 64(2), 161-175.

Jones, E. (2013). Internationalization and employability: The role of intercultural experiences in the development of transferable skills. Public Money \& Management, 33(2), 95-104.

Jones, E. (2016). Mobility, graduate employability and local Internationalisation. In E. Jones, R. Coelen, J. Beelen \& H. de Wit (Eds.), Global and Local Internationalization (pp. 105-116). Rotterdam: Sense Publishers.

Knight, J. (2004). Internationalization remodeled: Definition, approaches, and rationales. Journal of Studies in International Education, 8(1), 5-31.

Knight, J. (2015). Updated definition of internationalization. International Higher Education, 33, 2-3.

Leask, B. (2009). Using formal and informal curricula to improve interactions between home and international students. Journal of Studies in International Education, 13(2), 205-221.

Leask, B. (2016). Internationalizing curriculum and learning for all students. In E. Jones, R. Coelen, J. Beelen, \& H. de Wit (Eds.), Global and Local Internationalization. Transgressions: Cultural Studies and Education (pp. 49-53). Rotterdam: Springer.

Robson, S. (2017). Internationalization at home: Internationalizing the university experience of staff and students. Educação, 40(3), 368-374.

Rossini, M. O., Rincón, S., \& Rutkowski, A.-F. (2015). The link class project: Collaborative virtual teams between Peru and the Netherlands. Journal of Economics, Finance and Administrative Science, 20(39), 137-140.

Rubin, J. (2016). Nautical musings on local and global innovation and change: The disruptive pedagogy of COIL. In E. Jones, R. Coelen, J. Beelen \& H. de Wit (Eds.), Global and Local Internationalization (pp. 75-79). Rotterdam: Sense Publishers. 
Soria, K. M., \& Troisi, J. (2014). Internationalization at home alternatives to study abroad: Implications for students' development of global, international, and intercultural competencies. Journal of Studies in International Education, 18(3), 261-280.

Wolcott, H. F. (1990). Making a study "more ethnographic". Journal of contemporary Ethnography, 19(1), 44-72.

Yin, R. K. (2017). Case study research and applications: Design and methods (5th ed.). Thousand Oaks: Sage.

Belem Barbosa

Universidade de Aveiro, ISCA-UA

GOVCOPP (Portugal)

Email: belem.barbosa@ua.pt

Orcid: https://orcid.org/0000-0002-4057-360X

Claudia Amaral Santos

Universidade de Aveiro, ISCA-UA

GOVCOPP, CLLC (Portugal)

Email: claudia.amaral@ua.pt

Orcid: https://orcid.org/0000-0003-2630-294X

Claudia M. Prado-Meza

University of Colima (Mexico)

Email: claudiaprado@ucol.mx

Orcid: https://orcid.org/0000-0002-9820-7995

Correspondência

Belém Barbosa

Universidade de Aveiro, ISCA-UA

Rua Associação Humanitária dos Bombeiros Voluntários de Aveiro 3810-500 Aveiro, Portugal

Data de submissão: Março 2019

Data de avaliação: Maio 2019

Data de publicação: Abril 2020 